\title{
Dignity, religion and freedom of expression in South Africa
}

\author{
Author: \\ Jacobus C.W. van Rooyen ${ }^{1,2}$ \\ Affiliations: \\ ${ }^{1}$ Broadcasting Complaints \\ Commission of South \\ Africa, South Africa \\ ${ }^{2}$ Department of Systematic \\ Theology and Christian \\ Ethics, University of \\ Pretoria, South Africa \\ Note: \\ Prof. Dr Kobus van \\ Rooyen (SC, BA, LLB, LLD) \\ participates as research \\ associate of Prof. Dr \\ Johan Buitendag, Dean of \\ the Faculty of Theology \\ at the University of \\ Pretoria and Professor \\ in Systematic Theology \\ and Christian Ethics. \\ Professor Van Rooyen \\ is Emeritus Professor of \\ Criminal Law, University \\ of Pretoria (1971-1998); \\ Chair of the Broadcasting \\ Complaints Commission \\ of South Africa 1993-; \\ Chair of the Publications \\ Appeal Board 1980-1990; \\ Executive Councillor \\ of the Independent \\ Communications Authority \\ of South Africa 2006-; \\ Fellow of the Alexander \\ von Humboldt Stiftung, \\ Germany 1974-; (1998- \\ 2006); Deputy Chair \\ Tuks Alumni 2002-2008; \\ Chair of the Press Counci \\ (1991-1997); Chair of the \\ Ministerial Task Group \\ Films and Publications \\ Act (1994-1996); Senior \\ Counsel at the Pretoria Bar \\ (1998-2006).
}

Correspondence to:

Kobus van Rooyen

email:

kobusvrooyen@telkomsa.net

Postal address:

Rigellaan Suid 262,

Waterkloofrif, Pretoria

0181, South Africa

Dates:

Received: 31 Jan. 2011

Accepted: 05 Feb. 2011

Published: 07 June 2011

How to cite this article:

Van Rooyen, J.C.W., 2011,
The issue that this article dealt with is whether, in South African law, speech that infringes upon the religious feelings of an individual is protected by the dignity clause in the Constitution of the Republic of South Africa. The Constitution, as well as the Broadcasting Code, prohibits language that advocates hatred, inter alia, based on religion and that constitutes incitement to cause harm. Dignity, which is a central Constitutional right, relates to the sense of self worth which a person has. A Court has held that religious feelings, national pride and language do not form part of dignity, for purposes of protection in law. The Broadcasting Complaints Commission has, similarly, decided that a point of view seriously derogatory of 'Calvinistic people' blaming (some of) them as being hypocritical and even acting criminally is not protected by dignity. It would have to be accompanied by the advocacy of hatred as defined previously. The author, however, pointed out that on occasion different facts might found a finding in law that religion is so closely connected to dignity, that it will indeed be regarded as part thereof.

\section{Introduction}

One of the most problematic areas in South African law is that of the limits to freedom of expression. In 1994 South Africa became a Constitutional democracy with a Bill of Rights as part of its Constitution. The contrast with the old apartheid South Africa is phenomenal. The supremacy of the Constitution stepped into the supremacy of Parliament, which could before 1994 make any law it wished to make, including laws that ensured that the majority of Black and Coloured people could not vote.

With freedom, however, also came a new paradigm for freedom of expression. The Minister of Home Affairs appointed a Task Group in August 1994 to advise him as to the constitutionality of the Films and Publications Act 1974. This Act placed all films aimed at being shown in public, all publications (except newspapers under the Press Council) and public entertainment under the control of a Directorate with its publications committees. There was an appeal to a Publications Appeal Board. From there, only review to the Supreme Court with three judges was provided for. The Task Group advised the Minister that the 1974 Act was unconstitutional in many respects and drafted a Bill, which was accepted by Parliament in 1996 without any substantial amendment. The new Act would not include terms such as indecent, obscene, offensive or harmful to public morals, blasphemy and offensive to the religious convictions or feelings of a section of the population. Only films screened in public and publications, with the exception of newspapers under the Press Council, would fall under the Films and Publications Board. Broadcasting would fall under the Independent Broadcasting Authority and if the broadcasters set up their own disciplinary mechanism, that mechanism would deal with complaints from the public against broadcasters. The test in the case of religion would be whether the publication or film amounted to the advocacy of hatred based on race, ethnicity, religion or gender that constituted incitement to cause harm. This amounted to a radical change from the vague test of offensiveness and blasphemy, the latter being limited to the protection of the Judaic-Christian God, with the added perspective in Christian religion of Jesus and the Holy Spirit. I was privileged to have been the Chairman of the Publications Appeal Board from 1980-1990 and to Chair the Ministerial Task Group from 1994-1996. I have also chaired the Broadcasting Complaints Commission (BCCSA) since 1993

In 1993 the National Association of Broadcasters had already set up the BCCSA, which has been functioning since that time and has dealt with more than 18000 complaints by 2011 . Whilst the film Jesus Christ Superstar had already been passed for theatre screening by a progressive Appeal Board by 1983, a film that enraged Christians internationally was Martin Scorcese's The Last Temptation of Christ. The film added a fourth temptation of a momentary longing of Jesus to have lived an ordinary life in which he could wed and have children. For 40 minutes the film then shows this momentary longing being put over into marriage with Mary Magdalene and after she dies, with Mary the sister of Martha and Lazarus. An inexplicit matrimonial sex scene is 
'Dignity, religion and freedom of expression in South Africa', HTS Teologiese Studies/Theological Studies 67(1), Art. \#1030, 6 pages. DOI:10.4102/hts. v67i1.1030
(C) 2011. The Authors. Licensee: OpenJournals Publishing. This work is licensed under the Creative Commons Attribution License. included. Ultimately, after a second or two in real time, Jesus is shown on the Cross again, asking his Father's forgiveness for this momentary temptation.

When the Publications Appeal Board refused a certificate for the screening of the film in 1989, it functioned in terms of section 47(2)(b) of the Publications Act 1974. I chaired the Publications Appeal Board at the time and the judgment, which denied a certificate, is partly published in Prentice Hall Weekly Legal Services (1989). The two criteria that the Act prescribed were that if a film was offensive to the religious convictions or feelings of a section of the population, or if it was blasphemous, it would be deemed to be undesirable. The Appeal Board, in spite of its very freedom-oriented approach towards art and drama, unanimously held that the film was offensive to the religious convictions or feelings of a section of the population. It was not deemed necessary to decide whether the film was also blasphemous.

Whilst the question in 1989 was whether the film was 'offensive', the question in terms of the Broadcasting Code (as well as the Films and Publications Act 1996) is whether it amounts to the 'advocacy of hatred based on religion and that constitutes incitement to cause harm.' Bona fide drama is, inter alia, exempted. Artistic creativity (and one of its products, film drama, which would include broadcasts) and scientific research (and one of its products, the film documentary) have in the past 30 years often challenged the boundaries as initially set by Parliament for visual media. The Films and Publications Act 65 of 1996 exempts bona fide art, drama, literature and scientific publications, from the classification XX or X18.

In 1999 the new Films and Publications Board approved the distribution of the film by way of video and DVD. There was an outcry from the Christian public and the Board denied a certificate for the screening of the film in theatres. Video Vision Enterprises lodged an appeal that was, however, withdrawn when the international distributers of the film withdrew its distribution. In 2008 e-tv, a free-to-air broadcaster, broadcast the film at 23:15 with an age restriction of 18, as well as a classification informing viewers that the film contained scenes of violence. More than 1200 complaints were filed with the BCCSA. The complaints were mostly orchestrated and on that ground, not entertained by the Registrar. However, a complaint by the Wesleyan Church was entertained and heard. A majority of the Tribunal voted that the film amounted to the advocacy of hatred based on religion in its addition of a final temptation and that the film did not amount to a bona fide drama, given that the producers must have known that the film would offend millions of Christians. I filed a minority opinion which was, on different grounds, upheld on appeal by the BCCSA Appeal Tribunal. The Appeal Tribunal, presided over by Commissioner (Rev.) Danie du Toit with the well-known Prof. Wilhelm Jordaan (columnist, poet and psychologist) as one of the members, held that the film was of exceptional dramatic merit and that, once again, Jesus had not given in to the 'last temptation'. The outcome was that e-tv had not contravened the Broadcasting Code by having broadcast the film.

A question that arose at the first level and with which I dealt in my minority opinion in Last Temptation, was whether the dignity of a person, in itself, also includes the religious precepts of that person. Under the 1974 Films and Publications Act, dignity was most certainly part of the conglomerate of interests that were protected under the standard of 'offensive to the religious convictions or feelings of a section of the population'. The definition of blasphemy also includes a reference to the dignity of God, inasmuch as blasphemy is defined, even in its limited juridical sense, as scandalising God, or, in a Christian sense, any member of the Trinity (see R v Webb 1934, AD 493; Publications Control Board v Gallo (Africa) Ltd 1975(3) SA 665(A) 671H).

However, in terms of section 39(2) of the Constitution this definition of blasphemy must be interpreted within the limits of hate speech. Blasphemy will, accordingly, only be legally relevant if God is denigrated in a manner that complies with hate speech, namely, the advocacy of hatred based on religion that constitutes incitement to cause harm. I have argued earlier in HTS Theological Studies that the crime of blasphemy will remain constitutionally valid if applied in this fashion (Van Rooyen 1995:1127-1133).

\section{Returning to dignity}

Dignity, as a legal concept, has its roots in Roman law and has been developed in such a fashion that it has led to sprouts in the form of privacy and reputation, as independent rights of personality (see Joubert 1953; Neethling [1979] 1991). In essence, dignity is the sense of self worth that an 
individual has. That dignity is an all-important constitutional right, was emphasised by Justice O'Regan (in 'Khumalo and Others v Holomisa' 2002 [5] SA 401 [CC] at para [22]). The learned Justice of the Constitutional Court said the following regarding dignity:

[27] In the context of the actio injuriarum, our common law has separated the causes of action for claims for injuries to reputation (fama) and dignitas. Dignitas concerns the individual's own sense of self-worth, but included in the concept are a variety of personal rights including, for example, privacy. In our new constitutional order, no sharp line can be drawn between these injuries to personality rights. The value of human dignity in our Constitution is not only concerned with an individual's sense of self-worth, but constitutes an affirmation of the worth of human beings in our society. It includes the intrinsic worth of human beings shared by all people as well as the individual reputation of each person built upon his or her own individual achievements. The value of human dignity in our Constitution therefore values both the personal sense of self-worth as well as the public's estimation of the worth or value of an individual.

The Broadcasting Code prohibits broadcasts that invade the dignity, privacy or reputation of any person, unless it is in the public interest to do so. 'Public interest' does not, of course, mean that which interests the public. It means a higher interest, which would, for example, be constituted by truth and contributing to the public's constitutional right to be informed.

Before a view on whether dignity includes religious feelings can be put forward, it is necessary to look at the Constitutional paradigm within which the BCCSA (and also the Courts, if they were to be called upon to decide the issue) may, in my view, come to decisions as to what is permissible in broadcasts.

The paradigm within which the Tribunal is obliged to function has been developed by the Constitutional Court in the light of the Bill of Rights. A few facets of this paradigm are discussed here:

- The opinion of a majority of South Africans does not necessarily decide what is constitutionally compatible. The rights of minorities and individuals are also protected in appropriate cases. It is true that Parliament represents the electorate and that the Constitutional Court has held that Parliament has the right to protect morality. But the Constitutional Court goes on to define that morality in terms of constitutional morality. ${ }^{2}$ The Court has thus moved away from necessarily holding itself bound by the perceived moral beliefs of the majority of voters. What counts is the Bill of Rights, which is sovereign. ${ }^{3}$ That

1.See Clause 14 (previously clause 38) of the Broadcasting Code, which may be found on the BCCSA website: www.bccsa.co.za.

$2.5 v$ Jordan and Others (Sex Workers Education \& Advocacy Task Force \& Others as Amici Curiae) 2002(6) SA 642(CC); Prince v President, Cape Law Society 2002 (2) SA 794 (CC).

3.As required by the Rule of Law. The BCCSA has constantly aspired to understand its functions within a constitutional paradigm, as it is, in any case, obliged to do in terms of section 39 of the Constitution. See Rogers v SABC 2003(4) BCLR 439 (BCCSA) where the following judgments are referred to: Fedsure Life Assurance $v$
Greater Johannesburg Transitional Metropolitan Council 1999 (1) SA 374 (CC) and Greater Johannesburg Transitional Metropolitan Council 1999 (1) SA 374 (CC) and
President of the Republic of South Africa v South African Rugby Football Union 2000 (1) SA 1 (CC) at para [148] where it was held that the holder of public power must act in good faith and not misconstrue its powers. is why the Court, for example, rejected the pro-death sentence view that, it conceded, was held by the majority of South Africans in serious cases involving murder. ${ }^{4}$ The individual's right to life and not to be subjected to arbitrary punishment and torture was dominant. There is also little doubt that same-sex marriages are not supported by the majority in Parliament or by the majority of South Africans; yet Parliament was ordered by the Constitutional Court to provide for such unions in legislation. ${ }^{5}$ Unreasonable discrimination against same-sex partners was at the heart of the order. In the same matter, the Court also rejected religious doctrine as a source for the interpretation of the Constitution, emphasising instead freedom of choice. ${ }^{6}$ Since, according to our Constitution, the South African State is a secular State where freedom of religion and opinion is a fundamental right, this approach is, with respect, correct. Of course, it is true that religion plays an important role in structuring society, but given the basic differences between religions, which should nevertheless constitutionally be regarded as equal, it would be impossible to permit religious doctrine or principles to guide interpretation of the Constitution. Freedom of religion is guaranteed and insofar as the freedom to express that religion is concerned, this freedom finds its only hate speech limitation in section 16(2)(c) of the Constitution, which expressly refers to religion as one of the four grounds on which a complaint of hate speech may be based. Accordingly, offensive religious speech is permitted, as long as such speech does not amount to the advocacy of hatred based on religion and which constitutes incitement to cause harm.

- The importance of the protection of minorities has also been a recurring theme in judgments of the Constitutional Court. ${ }^{7}$ When the Broadcasting Complaints Tribunal held the broadcast of the song Amandiya of well-known songwriter, Mbongeni Ngema, to be in contravention of the Broadcasting Code, it accentuated the protection of the perceptions and right to security of the minority Indian community in Durban. ${ }^{8}$

- An important aspect of Constitutional Court doctrine is that freedom of expression includes the right to express

4.S v Makwanyane and Another 1995 (3) SA 391 (CC).

5.Minister of Home Affairs v Fourie (Doctors for Life International and Others, Amici Curiae); Lesbian and Gay Equality Project and Others v Minister of Home Affairs 2006(1) SA 524(CC)

6.'It is one thing for the Constitutional Court to acknowledge the important role that religion plays in our public life, and quite another for it to use religious doctrine as a source for interpreting the Constitution. It would be out of order to employ the religious sentiments of some as a guide to the constitutional rights of others. Judges religious sentiments of some as a guide to the constitutional rights of others. Judges
would be placed in an intolerable situation if they were called upon to construe rewould be placed in an intolerable situation if they were called upon to construe re-
ligious texts and take sides on issues that have caused deep schisms within religious ligious texts and take sides on issues that have caused deep schisms within religious
bodies.' (Paragraph [92] of the judgment). 'The Constitution contains a number of bodies.' (Paragraph [92] of the judgment). 'The Constitution contains a number of
provisions that underline the constitutional value of acknowledging diversity and provisions that underline the constitutional value of acknowledging diversity and pluralism in our society, and give a particular texture to the broadly phrased right people to self-expression without being forced to subordinate themselves to the cultural and religious norms of others, and highlight the importance of individuals and communities being able to enjoy what has been called the 'right to be different'. an each case, space has been found for members of communities to depart from majoritarian norm. (Paragraph [61] ) [Quotes from the headnote of the judgment].

7.Christian Education South Africa v Minister of Education 2000 (4) SA 757 (CC); Prince $v$ President Cape Law Society, and Others 2002 (2) SA 794 (CC).

8.South African Human Rights Commission v SABC 2003(1) Butterworths Constitutional Law Reports 92(BCCSA). 
offensive ideas. ${ }^{9}$ The limitation of section 36 of the Constitution would, of course, apply. Nevertheless, the starting point is of particular significance. Under pre-1996 publications and films legislation, 'offensive' to public morals or religious convictions or feelings of a section of the population, was an important basis for banning. The Appellate Division banned the Gallo edition of the gramophone record of Jesus Christ Superstar in 1975 on the grounds of its being offensive to the religious convictions of Christians. ${ }^{10}$ The language in Lady Chatterley's Lover and Magersfontein, O! Magersfontein was, before the 1980s, rejected purely on the grounds of being offensive to public morals and in certain respects, offensive to the religious convictions or feelings of the Christian section of the population. In 1974 the Cape Supreme Court banned the novel Kennis van die Aand, finding it to be offensive to the religious convictions or feelings of the Christian section of the population. ${ }^{11}$ In the 1980 s, these novels were unbanned by the Publications Appeal Board with reference to literary merit, likely readership and context. ${ }^{12}$ In 1981 the film Jesus Christ Superstar was banned as being offensive, but two years later it was found to be not undesirable. ${ }^{13}$ Of course, one of the criteria for a banning on religious grounds was offensiveness to religious convictions or feelings. The Publications Appeal Board in 1989, in spite of its open-minded approach in other respects, found The Last Temptation of Christ to be offensive to the religious convictions or feelings of the Christian section of the population. The Films and Publications Board, acting under the new 1996 Act, held that the film in its video and DVD forms did not amount to hate speech and regarded the film, in any case, as bona fide drama in terms of Schedule 10 of the Act in 1999. The reason for the denial of a certificate for cinema distribution was that anonymous threats were received from some agitators, stating that they would attack theatres where the film was screened. ${ }^{14}$ It should be mentioned that differentiation of any kind between video and cinema distribution is not authorised by the Films and Publications Act of 1996. Had the said denial been considered on review, I have no doubt that it would have been held to have been ultra vires.

- Freedom of speech must be awarded a generous interpretation and be fully invoked at the outset when testing the facts in terms of clause 16, which allegedly applies to the facts before the court or tribunal. ${ }^{15}$ In Islamic Unity Convention $v$ The Independent Broadcasting Authority

9.De Reuck v Director of Public Prosecutions, WLD and Others 2004(1) SA 406 (CC).

10. Publications Control Board v Gallo(Africa) Ltd 1975(3) SA 665(A).

11. Buren Uitgewers (Edms) Bpk en ' $n$ Ander v Raad van Beheer oor Publikasies 1975(1) SA 379 (C). The book has been translated, inter alia, into English with the title Looking on Darkness.

12.As to Magersfontein O! Magersfontein unbanned in 1980 the report is in Human en Rousseau Bpk v Die Komitee oor Publikasies 1987(1) PH M19 (PAB); as to Kennis van die Aand unbanned in 1982 the report is in 1986(1) PH M14(PAB).

13.Direktoraat van Publikasies v Die Komitee oor Publikasies 1986 PH M18.

14.Confirmed by Mr lyavar Chetty, previously from the Films and Publications Board executive.

15.Laugh It Off Promotions CC $\vee S A B$ International (Finance) BV t/a Sabmark International (Freedom of Expression Institute as Amicus Curiae) 2006 (1) SA 144 (CC). and Others ${ }^{16}$, Deputy Chief Justice Langa (later on Chief Justice) convincingly contrasted the current state of freedom of expression with that of the restrictive past, as follows:

Notwithstanding the fact that the right to freedom of expression and speech has always been recognized in the South African common law, ${ }^{17}$ we have recently emerged from a severely restrictive past where expression, especially political and artistic expression, was extensively circumscribed by various legislative enactments. The restrictions that were placed on expression were not only a denial of democracy itself, but also exacerbated the impact of the systemic violations of other fundamental human rights in South Africa. Those restrictions would be incompatible with South Africa's present commitment to a society based on a 'constitutionally protected culture of openness and democracy and universal human rights for South Africans of all ages, classes and colours.

South Africa is not alone in its recognition of the right to freedom of expression and its importance to a democratic society. The right has been described as one of the essential foundations of a democratic society; one of the basic conditions for its progress and for the development of every one of its members. As such, it is protected in almost every international human rights instrument. In Handyside v The United Kingdom, the European Court of Human Rights pointed out that this approach to the right to freedom of expression is:

applicable not only to 'information' or 'ideas' that are favourably received or regarded as inoffensive or as a matter of indifference, but also to those that offend, shock or disturb ... Such are the demands of that pluralism, tolerance and broadmindedness without which there is no 'democratic society'.

The pluralism and broadmindedness that is central to an open and democratic society can, however, be undermined by speech which seriously threatens democratic pluralism itself. Section 1 of the Constitution declares that South Africa is founded on the values of 'human dignity, the achievement of equality and the advancement of human rights and freedoms.' Thus, open and democratic societies permit reasonable proscription of activity and expression that pose a real and substantial threat to such values and to the constitutional order itself. Many societies also accept limits on free speech in order to protect the fairness of trials. Speech of an inflammatory or unduly abusive kind may be restricted so as to guarantee free and fair elections in a tranquil atmosphere. (footnotes omitted).

Freedom of choice is an important facet of freedom of expression and is supported by the fundamental right to watch material, which includes even experimental drama. The decision to thwart the right of an adult to choose to see a film must be based on much more than one's personal experience of the film being offensive. The legal question

16.2002 (4) SA 294 (CC) at paragraph [27].

17.Footnotes omitted 
is whether a reasonable person, in casu, a Christian, would tolerate another person watching a broadcast of a film from $23 \mathrm{~h} 15$ onwards (with due classification) and not whether he or she would tolerate watching the film him- or herself. ${ }^{18}$ The effect of freedom of expression can, at times, be a painful experience, but that is the price one has to pay in a free and open democracy for the right to partake in that freedom.

The subjective intention of the producer is not relevant in determining whether the work is a bona fide drama. ${ }^{19}$ Bona fides relates to the question as to whether the drama is indeed, according to objective standards, a genuine drama. ${ }^{20}$

Threats of violence if a finding is made in favour of a film that may be problematic in religious terms, are irrelevant in an adjudication. Of course, if the material itself advocates violence, that would place it in the category of hate speech. When Judge Jajbhay ${ }^{21}$ interdicted newspapers from publishing cartoons of the prophet Mohamed, he based the interdict on the protection of the dignity of Muslims regarding their religious adherence to the teachings of the Prophet. There was, rightly, no reference to threats of possible violence in the conclusion reached by the Court, in spite of this aspect having been raised by the applicant in its papers before the Court.

The aspect of dignity will be dealt with in the next paragraphs.

A complaint that combined religion and dignity was lodged with the BCCSA at the end of 2010. The complainant had heard a presenter say, during a midnight debate on hypocrisy on radio, that what bothered him of 'Calvinistic' people was that they were the very people one found in brothels. The Complainant argued that although this did not amount to hate speech, the words did offend him as Calvinist and deeply so. The BCCSA Tribunal quoted the following dictum from Judge Nicholas in $S v$ Tanteli $^{22}$ :

In my view, however, there was in the present case no basis for a finding that the complainant's dignitas (his proper pride in himself) was impaired at all. The attack was not, and was not understood as being, an attack against the complainant personally. It was an attack upon his language. Undoubtedly, the complainant found that to be hurtful and offensive in a general sense; but it did not, in relation to the person of the complainant, have that degrading, insulting or ignominious character which is a requisite of an injuria.

In our mixed society there are, apart from language, a number of

18.See South African Connexion cc T/a Reel Communications v Chairman, Publication Appeal Board 1996 (4) SA 108 (T). Streicher J (as he then was) states, on behal of the Full Transvaal Bench: 'The issue, in my view, is what the community will tolerate in its midst, not what members thereof might themselves be offended by seeing. In my view, that concept was aptly stated by the Canadian Supreme Court in Towne Cinema Theatres Ltd $\vee R$ (1985) 18 DLR (4th) 1 ([1985] 1 SCR 494) in the following terms: 'The cases all emphasise that it is standard of tolerance, not taste that is relevant. What matters is not what that is relevant. What matters is not what Canadians think is right for themselves to see. What matters is what Canadians would not abide other Canadians seeing because it would be beyond the contemporary Canadian standard of tolerance to

19.See De Reuck v Director of Public Prosecutions, WLD and Others 2004(1) SA 406 (CC) at para [32].

20.See Publications Control Board v Central News Agency Ltd 1977(1) SA 717(A).

21.See Jamiatal - UI-Ulama of Transvaal v Johncom Media Investment Ltd and Others WLD case 1127/06.

22.1975(2) SA 772(T) where the following words were said by Tanteli to the complainant (an Afrikaans speaking person who wished to be served in Afrikaans) 'Whatever you are speaking, speak to the Kaffir'. areas, such as race, religion, colour and national feeling, in which an individual may be exceptionally sensitive to disparaging remarks and over the years there must unhappily have been innumerable instances in which an individual has felt himself affronted by offensive remarks in one or other of these areas. The fact that it appears that there is not on record any case of a prosecution for criminal injuria arising out of such remarks, points strongly to the conclusion that conduct such as that now in question has never been regarded as supporting a criminal charge.

Bearing in mind the past history of criminal administration in this country, the position seems to me to be correctly stated in Gardiner and Lansdown, S. A. Criminal Law and Procedure... that criminal injuria has a narrower denotation in this country than injuria had in the Roman-Dutch law, and that, even if conduct falls within the Roman-Dutch definition of injuria, the Courts of this country will not treat it as a criminal injury if it is not of a reprehensible character which in the interests of society should be punished, or if there has for a long period been a practice by which such conduct has been regarded as not constituting a contravention of the criminal law.

There may, of course, be cases in which an insult to a person's language, or race or religious persuasion or national group may, in the circumstances, constitute also an impairment of his dignitas, but this is not such a one.

The BCCSA $^{23}$ argued as follows in adjudicating the 'Calvinistic' complaint. The first question was whether religion may also be accommodated under the dignity clause, that is clause 38 of the Broadcasting Code. Is clause 16, in its explicit protection against hate speech based on religion, not the only clause that protects religion? ${ }^{24}$ Would one not always resort to dignity as soon as the stringent requirements of the hate speech clause 16 have not been met? The BCCSA was not convinced that the invasion of dignity, within the context of the Broadcasting Code, was a constitutionally permissible limitation to speech that is regarded as offensive on religious grounds. Section 16(2)(c) of the Constitution explicitly states that hate speech based on religion is not permitted. The same limitation is found in the BCCSA Code. That is the only limit to free speech in the case of religion. If the infringement of the right to dignity were to be the test, recourse would always be had to this in unsuccessful complaints relating to hate speech. The unlawful infringement of the right to dignity could then be based on mere offensiveness to the complainant, without a hate speech component to it. Where dignity is impaired, there could be compliance with the 'harm' requirement in the hate speech definition. However, to that the advocacy of hatred would have to be added, which was absent in the 'Calvinistic' broadcast. The infringement of the right to dignity alone is, however, not a sufficient ground to impose a limitation on offensive religious speech. At the heart of freedom of religion lies the right to express views that could be offensive to adherents of the faith that is being criticised or attacked. The BCCSA, accordingly, did not agree with the Court's approach in the Jamiat-Ul-Ulama ${ }^{25}$ judgment where the finding would seem to have been based only on

23. De Waal $v$ Talk Radio 702 (case 32/2010) which may be read on the website of the BCCSA with the Broadcasting Code at www. bccsa.co.za

24.The advocacy of hatred based on race, ethnicity, religion or gender that constitutes incitement to cause harm.

25.Jamiat-Ul-Ulama of Transvaal v Johncom Media Investment Ltd and Others, Case No. $1127 / 06$ (WLD) 
the infringement of the right to dignity of adherents of the Islamic faith. Although not fully discussed, the learned Judge does, however, also find that there was an advocacy of hatred and, combined with the infringement of the right to dignity, the Court, ultimately, in my view did base its conclusion on the advocacy of hatred as well as the infringement of the right to dignity. Of course, it should then be accepted that the hate speech also constituted incitement to cause harm in terms of section 16(2) of the Constitution. The judgment, in any case, provides no grounds to limit the right of a broadcaster, through a presenter, to express a view on the hypocrisy of 'Calvinistic' people. Vitriolic, as it was to make this sweeping statement, it did not satisfy the requirement of propagation of hatred.

\section{Conclusion}

It should be noted that both the BCCSA and Judge Nicholas left open the question whether there might not be cases where religion is so intertwined with dignity that the attack, judged as a whole, would ultimately infringe dignity, even from a legal perspective. In this sense, the law is always open to adapt to facts which, indeed, infringe dignity as protected by law.

\section{Acknowledgement}

I have known Andries van Aarde since his school days. He has always inspired me by his independence, capacity to do in-depth research and his extraordinary courage in opening up the depths of the New Testament and publishing his findings. I have enjoyed reading what he has written during the last two decades. I wish him all of the best and thank him sincerely for the work he has done.

\section{References}

Joubert, W.A., 1953, Grondslae van die persoonlikheidsreg, Balkema, Kaapstad. Justice O'Regan, 2002, 'Khumalo and Others v Holomisa', 2002 (5) SA 401 (CC) at para [22].

Neethling, J., [1979] 1991, Persoonlikheidsreg, 3de druk, Butterworths, Durban.

Prentice Hall Weekly Legal Services, 1989, 'United International Pictures (S.A.) v The Committee of Publications', 1989, PH M18(PAB) (case number 125/88).

Van Rooyen, J.C.W., 1995, 'Does the offence of blasphemy have a future under the South African Constitution?', HTS Teologiese Studies/Theological Studies 51(4), 1127-1133 